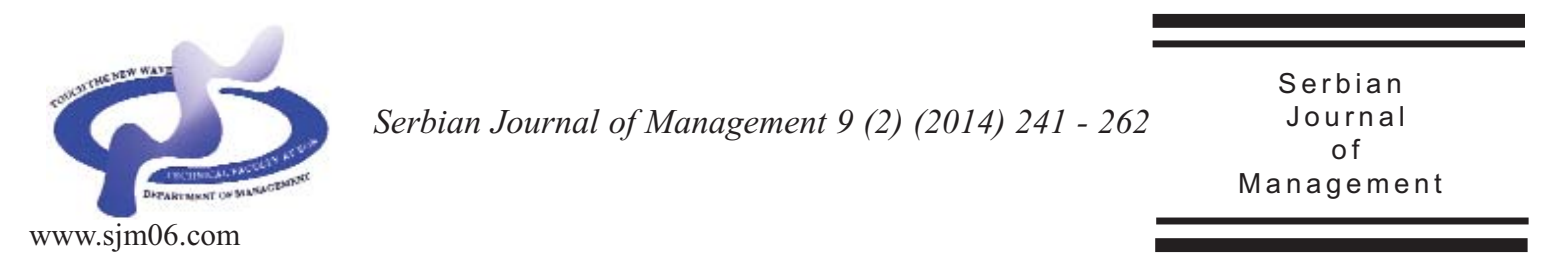

\title{
ORGANIZATIONAL ROUTINES IN RUSSIAN COMPANIES: REVIEW OF PRACTICES
}

\author{
Olga Valieva $\mathbf{a}^{\mathbf{a}} \mathbf{b} *$ \\ $a_{\text {Institute of Economic and Industrial Engineering of Siberian Branch of }}$ \\ Russian Academy of Science, Novosibirsk, Russia \\ $b_{\text {Novosibirsk State University, Novosibirsk, Russia }}$
}

(Received 26 June 2014; accepted 28 July 2014)

\begin{abstract}
Results of the first stage of the researches conducted in 2012-2013 are presented in article. Researches are connected with studying of transformational processes intra corporate of managemetn practices in the Russian companies and their subsequent institutionalization. Preliminary results showed that in the companies there is a standard set of organizational routines which part are information, and administrative routines, routines of the power of the founder, genetic, institutional and development routines. During research statistically significant connection between types of organizational structures, the sizes of the organization, information processing and administrative practices is established. It is revealed as change of approaches to management of the organization can affect a corruption component.
\end{abstract}

Keywords: organizational routines, institutional elements, organizational structure, information processing, management of practices, decision-making, centralization, corruption, transactional costs

\section{INTRODUCTION}

Now influence of organizational routines on efficiency of activity of the organizations and adoption of administrative decisions is widely discussed within the directions on Social and Organizational psychology,
Organizational sociology, Organization Theory, Organizational learning, Organizational culture, Institutional Theory, Evolutionary Theory, Routine Activity Theory, Theory of organizational routines and capabilities and others.

The concept "routines as memories of the

\footnotetext{
* Corresponding author: O_valieva@mail.ru
}

DOI:10.5937/sjm9-6362 
organization" was entered by R. Nelson and S. J. Winter. They noted that "the rutinization reflects achievements of coordination and formation of memory of the organization supporting this coordination" and routine functioning is self-sustaining (Nelson \& Winter, 1982). At the same time, authors allocated aspects of "a rutinization of innovations" according to which the organizations have to have routines which are supported by innovative efforts and practices. Feldman and Pentland treat concept definition of organizational routines as "repetitive, recognizable patterns of interdependent actions, carried out by multiple actors" (Feldman \& Pentland, 2003). In one of the latest works of S. J. Winter, addressing to John Dewey works, emphasizes importance of transferring of the analysis of organizational routines on level of the individual actor and inclusion in the analysis of psychological aspects, (Winter, 2013).

\section{THEORETICAL APPROACHES AND HYPOTHESES}

As a whole researches on organizational routines can be divided into three vectors. The first vector in the center of the analysis puts the certain actor and focuses attention on micro-foundations of routines (Abell et al., 2008; Felin \& Hesterly, 2007; Felin et al., 2012). "The microfoundations of organizational routines and capabilities include constituent components (i.e. main effects) - individuals, processes, and structure; and interactions within and across components (i.e. interaction effects) - the interactions of individuals, processes, and structures that contribute to the aggregation and emergence of the collective constructs" (Felin et al., 2012).
Within organizational psychology motivations and incentives, and also connection of organizational routines and habits are studied. (Becker, 2005; Cohen \& Bacdayan, 1994; Gioia \& Poole, 1984; Verplanken \& Aarts, 1999; Limayem et al., 2007; Ortiz de Guinea \& Markus, 2009; Wood \& Neal, 2007 ets.).

The second vector of researches is directed on studying of influence of macro level on organizational routines and dynamic capabilities (Helfat et al., 2007; Teece, 2012; Teece et al., 1997; Winter, 2003; Winter, 2013). Pentland, B.T., Feldman, M.S. and coauthors consider actions as a starting point for the study organizational routines and as an alternative micro-foundation. Authors claim that "macro-level dynamics of routines emerge from the micro-level relationship between specific actions and patterns of action". (Pentland et al., 2012). It is research very interesting because demonstrated relation path dependence between performances and routines. Martin Friesl and Joanne Larty highlights two areas for future research: the political dimension of replication strategies and drift in the process of replication (Friesl \& Larty, 2013).

The third vector is an institutional approach which shows a role of institutes and developed administrative the practices in organization functioning. Institutional approach to research developed administrative the practices provides a better understanding about organization functioning as open system in constantly changing institutional environment.

In researches on the theory of the organization it is possible to allocate conditionally three approaches to studying of influence of institutes for intra organizational changes and interactions. The first approach considers the organizations as dependent on 
environment. According to researchers, such organizations build in the formal and informal norms incorporated from the institutional environment, in the set of own corporate rules and act as a certain passive link or the conductor in a chain of transfer of institutes with macro - on microlevel (Meyer \& Rowan, 1977; Meyer, 2008). In other case, institutsionalist consider reaction of the organizations to change of transactional expenses as a result of environment influence (Coase, 1937; Williamson, 1985: Williamson, 2000).

The second type of researches focuses attention that institutional elements usually arise in the organization, instead of because of external processes of coercion (Zucker, 1983; Zucker , 1987; Tolbert \& Zucker, 1983). As Zsuker claims: “... the organizations are an important source of an institutionalization of new action. Already institutionalized elements can "infect" other organizations with new legitimate practices" (Zucker, 1987). Authors of above-mentioned approaches claim that again arisen institutional elements, are easily transferred to the companies beginners and remain during the long period of time, possessing high resistance to changes (Nelson \& Winter, 1982).

Zsuker allocates three basic principles of an organizational institutionalization (Zucker, 1987):

1. Institutional elements arise mainly in small groups or in the organizations at the level of processes;

2. Formalization of organizational structure and processes, as a rule, become a source of a new institutionalization;

3. The institutionalization increases stability of existence of the organization except for cases when more effective alternatives are ignored.
The third type of researches notes the dual nature of the organizations, considering that "... they are components of institutes and in too time form institutes" (Greif, 2006). The organization can be independent institute for the own personnel as forms intra corporate standards of behavior and the practices peculiar to this organization. A. Greif's approach is unique that in the center of research of the nature of institutes it places motivation which induces actors to conform to certain rules.

Thus, at specification of concept of organizational routine we were guided by the main assumptions:

1. The routine is a set of repeating actions of the individual or group of individuals at implementation of the professional activity within one organization;

2. Routines are inherited signs which can be transferred from one organization to another through knowledge of individuals (obvious and implicit), information (personalized and not personalized) and processes (administrative, technological, production, etc.)

3. The basic carrier of routine is the individual.

Hypothesis 1. For any organization a typical of organizational routines which reflects standard administrative practices is characteristic.

Hypothesis 2. Influence of the size of the company and type of organizational structures interdependent.

Hypothesis 3. The type of organizational structure and power distribution among shareholders/founders has linear dependence. The power among shareholders is more widely distributed, the it is more 
difficult organizational structures of management.

Hypothesis 4. Organizational structures are closely connected with intensity of processing of information streams and the organization sizes. The size of the organization and degree of intensity of information processing has impact on a choice of organizational structure.

Hypothesis 4-1. In the organizations with simple organizational structures and the small sizes processing, as a rule, oral and informal.

Hypothesis 4-2. In more formal and functional structures processing of information is more difficult, directed on communications and efficiency.

Hypothesis 4-3. In the decentralized organizational structures (matrix and divisional) information streams are directed on adaptation to fast-changing conditions of the market, and in divisions simple and oral forms of interactions prevail.

Hypothesis 4-4. In the companies with simple and functional organizational structures decision-making process is concentrated at the top level of business hierarchy. Thus information streams simple and oral.

Hypothesis 5. Decision-making centralization at the top level of organizational hierarchy leads to preservation of the enterprise and orientation of the company to domestic policy. The power among shareholders is more widely distributed, the risk of short circuit of the company, and concentration
Hypothesis 6. The progressive forms of government reduce risk of influence of corruption.

Hypothesis 7. Than the power among owners or shareholders is more widely distributed, subjects one company smaller the corruption component influences.

Hypothesis 8. The level of taxes is higher, the corruption is higher.

\section{RESEARCH METHODOLOGY}

The institutional space of the Russian business and its landscape are rather various. On the one hand are the formal norms having considerable impact on adoption of administrative decisions and the institutional environment as a whole, reflecting severe Russian reality. With another - the informal practiceswho are from part derivative of external influence of factors of institutional and a business environment, and from part developing under the influence of dynamics of sociocultural changes.

Our research was constructed on an assumption that eventually the defined organizational practices are transformed and corrections according to requirements of the changing institutional environment are exposed. We tried to understand, which organizational elements are exposed to changes to a greater or lesser extent as these changes depend on functional characteristics of the enterprises. Lester, Parnell and Carrakher's work which coordinated administrative practices to stages of life cycle of the studied companies (Lester et al., 
2003) was taken as a basis of our research.

Research set as the purpose to study influence of factors of the external and internal environment on structural changes in the companies, to reveal the general and distinctive features of organizational changes, to compare the revealed features with stages of life cycle of the organization.

The questionnaire contained twenty questions, and covered seven groups:

1. Enterprise size;

2. Structure of property and formal power;

3. Organizational structure of management;

4. Control, specialization and differentiation;

5. Processing of information streams in organization;

6. Decision-making processes;

7. Influence of transactional costs.

The main objectives of research were:

- Identification of factors of the environment influencing a choice of strategic priorities of the company;

- Identification of the internal factors having direct impact on decision-making processes in the organization ("a trap of the founder", information processing and so forth);

- Identification of prevailing type of organizational structure on types of the companies (the size, branch, forms of ownership and decision-making);

- Classification of the organizations by stages of life cycle;

- Comparison of strategy of development of the organization to types of organizational structures.

In our research we relied on surveys conducted with heads of 94 companies of Novosibirsk and the Novosibirsk region. The first stage of poll was carried out since
October 2012 till October 2013. Survey was conducted by a method of the profound semi-structured interviews. Polls covered:

- Regional divisions of the international companies;

- Large federal companies which are branches or regional representations;

- Large Novosibirsk enterprises;

- Enterprises of medium and small business.

The branch orientation of the companies was allocated on the basis of the OKVED codes. From 94 respondents of the companies the bulk is occupied in a services sector $-28,7 \%$, in wholesale and retail trade $-18 \%$, in production of food $-8,5 \%$, transport and communication $-5,3 \%$. Also heads of the companies participated in poll from spheres of production of mechanisms, machineand the equipment, electric equipment, distribution of the electric power, agriculture, financial activity and so forth.

As for answers to questions we used an interval scale from 1 to 5 (where $1-$ I absolutely not agree, 2 - I don't agree, 3 - it is neutral, 4 - I agree, and 5 - I completely agree) submitting to normal distribution, as the main characteristic used average value (Appendix A). Average values of answers of respondents are given in table 1 on questionnaire questions.

\section{RESULTS AND DISCUSSION}

Hypothesis 1. For any organization a typical of organizational routines which reflects standard administrative practices is characteristic.

The factorial analysis which has been carried out by the Method of main a component (Principal Component Analysis) at use of a method of rotation of Varimax 
revealed six groups of independent variables. The cumulative percent of the explained dispersion made 62,513\% (Appendix B).

The factorial analysis allowed to allocate six types of routines (Table 1) which all interrogated companies should face. The first group of routines which we designated as "Information routines", included the variables characterizing forms of information processing and connected with rather difficult organizational structures.

The second group included "Administrative routines", including modern styles and methods of adoption of administrative decisions. The third group "A trap of the founder", included only one indicator characterizing the preserved condition of the enterprise, growth locked at a stage and being in a "manual control" mode (Adizes, 2008). The fourth group "Genetic routines", routines which are peculiar to all companies at the initial stages of development. The fifth - "Institutional routines", expenses which included both tax, and corruption components. The sixth "Development routines", the routines,

Table 1. Types of routines

\begin{tabular}{|c|c|c|c|c|c|c|}
\hline & \multicolumn{6}{|c|}{ Routines } \\
\hline & Inform. & Admin. & $\begin{array}{l}\text { Trip of } \\
\text { founder }\end{array}$ & Genetic & Instit. & Devel. \\
\hline 1. Small companies & $-0,724$ & 0,200 & 0,223 & $-0,224$ & 0,020 & $-0,002$ \\
\hline 2. Medium-sized and large companies & 0,482 & $-0,364$ & $-0,032$ & 0,374 & $-0,066$ & 0,198 \\
\hline 3. Power of shareholders & 0,362 & 0,019 & $-0,666$ & 0,066 & $-0,125$ & 0,157 \\
\hline 4. Power of the founder & 0,002 & $-0,108$ & 0,785 & 0,075 & 0,057 & 0,010 \\
\hline 5. Power of several owners & 0,054 & 0,131 & $-0,353$ & 0,015 & $-0,435$ & 0,542 \\
\hline 6. OS: The simple linear & $-0,799$ & $-0,005$ & 0,165 & $-0,124$ & $-0,012$ & 0,043 \\
\hline 7. OS: Functional & 0,181 & 0,294 & $-0,185$ & 0,669 & 0,144 & $-0,077$ \\
\hline 8. OS: Divisional/matrix & 0,814 & 0,078 & $-0,070$ & $-0,205$ & 0,090 & 0,084 \\
\hline $\begin{array}{l}\text { 9. Centralization, not numerous } \\
\text { monitoring systems }\end{array}$ & $-0,632$ & $-0,217$ & 0,131 & 0,403 & $-0,089$ & $-0,022$ \\
\hline $\begin{array}{l}\text { 10. Existence of specialization and } \\
\text { gradual differentiation }\end{array}$ & 0,102 & 0,036 & $-0,054$ & 0,011 & 0,214 & 0,762 \\
\hline 11. IP: Simple oral form & $-0,743$ & $-0,241$ & $-0,086$ & $-0,207$ & $-0,149$ & $-0,053$ \\
\hline $\begin{array}{l}\text { 12. IP: Simple, are directed on intra } \\
\text { corporate communications }\end{array}$ & 0,359 & 0,318 & 0,249 & 0,523 & $-0,024$ & 0,331 \\
\hline $\begin{array}{l}\text { 13. IP: Are formalized and difficult, } \\
\text { directed on improvement of internal } \\
\text { processes }\end{array}$ & 0,674 & 0,233 & $-0,073$ & 0,292 & 0,165 & $-0,029$ \\
\hline $\begin{array}{l}\text { 14. IP: Are difficult, directed on fast } \\
\text { reaction to external changes }\end{array}$ & $\mathbf{0 , 5 3 1}$ & 0,467 & 0,238 & 0,012 & 0,163 & 0,069 \\
\hline $\begin{array}{l}\text { 15. Decision-making centralization at the } \\
\text { top level }\end{array}$ & $-0,062$ & $-0,232$ & 0,239 & 0,492 & $-0,001$ & $-0,412$ \\
\hline $\begin{array}{l}\text { 16. Decisions are made by group of top } \\
\text { managers }\end{array}$ & 0,156 & 0,784 & $-0,024$ & 0,036 & $-0,098$ & 0,236 \\
\hline $\begin{array}{l}\text { 17. Decisions are made by managers, } \\
\text { design teams and target groups }\end{array}$ & 0,051 & 0,787 & $-0,161$ & 0,101 & 0,021 & 0,034 \\
\hline $\begin{array}{l}\text { 18. Decisions are made by limited group } \\
\text { of managers, with conservative approach }\end{array}$ & 0,216 & $-0,211$ & $-0,295$ & 0,112 & 0,177 & $-0,430$ \\
\hline 19. Tax legislation & 0,186 & 0,014 & 0,141 & $-0,009$ & 0,645 & $-0,068$ \\
\hline 20. Corruption & 0,036 & $-0,005$ & $-0,039$ & 0,083 & $\mathbf{0 , 8 4 2}$ & 0,145 \\
\hline
\end{tabular}

Extraction Method: Principal Component Analysis.

Rotation Method: Varimax with Kaiser Normalization. Rotation converged in 11 iterations. 
allowing to assume a course of further development of the company: from power distribution among several founders/shareholders before introduction of specialization and the subsequent differentiation.

As a result of the carried-out factorial analysis we can specify concept of organizational routine as sets of information and administrative routines, routines of the power of the founder, genetic, institutional and development routines (Valieva, 2014).

Organizational structures and information process in the organizations

The structure of the organization carries out two main functions: 1) promotes to information passing in the organization and 2) to achievement of effective coordination and integration (Duncan, 1979). According to R. Duncan organizational structures need to be considered from the point of view of information streams.

Elements of structure have to correspond to the organization size, its age and a stage of life cycle, environmental conditions in which it functions, an available business model and the organization of the production cycle, used technology etc.

Key question for managers is the question of what optimum organizational structures to choose for the company as to transform it in the subsequent taking into account changing internal and external living conditions of the organization.

There is a number of researches of interrelations of organizational structure with the whole set of situational variables. Blau, Hage and Aiken, Hall, Lawrence and Lorsch and Chaild were pioneers of these researches. H. Mintzberg allocated five configuration of business and connected them with organizational structures (Mintzberg, 1979), communication of institutional and inertial restrictions with organizational structures was revealed in Hannan and Freeman works (Hannan \& Freeman, 1977).

Organizational information-processing Theory considers the organization as system of continuous information processing, connects changes of organizational structure of the company with dynamics and volume of information streams (Tushman \& Nadler, 1978; Huber, 1982; Egelhoff, 1991).

In our research we apply approach of a situational determinism at which a dependent variable is the type of organizational structure. There is a model according to which the structure is transformed under the influence of a set of independent variables. As a result of the regression analysis in structure of the independent situational variables influencing type of organizational structure, entered: the company size, extent of distribution of the formal power in the organization, centralization of adoption of administrative decisions, specialization and differentiation, and also forms and information processing methods in the organization.

In our work stable relations between type of organizational structure and information processing level were revealed. As technologies of information processing are characterized by different technological processes and depend on degree of progressiveness of used technologies, the hypothesis of influence of technologies on organizational structures which Woodward developed, Perrow, Hage and Aiken indirectly is confirmed.

The subsequent hypotheses were confirmed through carrying out the regression analysis. The regression analysis 
was carried out by a method Stepwise regression (Criteria: Probability-of-F-toenter $<=$,050, Probability-of-F-to-remove $>=, 100)$.

Hypothesis 2. Influence of the size of the company and type of organizational structures interdependent.

The correlation analysis showed (Pearson Correlation) that the size of the company is closely connected with type of organizational structure and an information processing form. For the small companies the simple organizational structure, centralization both not numerous monitoring systems and simple oral information transfers are significant. For the mediumsized and large companies the system of the information processing which has been welded on upon communications and increase of efficiency (Appendix C) is significant only.

In our research we received direct confirmation of influence of the size of the organization on its organizational structure (Table 2). Though J. Chaild claimed that influence of the size on structure no more than deterministic and is caused by factors of technological economy (Chaild, 1972).

According to results of regression model the small companies have simple organizational structure.
Hypothesis 3. The type of organizational structure and power distribution among shareholders/founders has linear dependence. The power among shareholders is more widely distributed, the it is more difficult organizational structures of management.

Usually involvement of new shareholders is connected with expansion of borders of business, an entry into the new markets, release of new type of production and diversification. Our research shows that organizational structures of management become complicated in process of involvement of new owners (Table 3).

For the companies with the sprayed property there is no importance of problems of "a trap of the founder".

Hypothesis 4. Organizational structures are closely connected with intensity of processing of information streams and the organization sizes. The size of the organization and degree of intensity of information processing has impact on a choice of organizational structure.

The correlation analysis showed that there are statistically significant communications between organizational structures and information processing. Simple organizational structures, as a rule, exists in the small companies with the centralized decision-making, not numerous monitoring

Table 2. Size of the company and type of organizational structure

\begin{tabular}{|c|c|c|c|c|c|c|c|c|c|c|}
\hline \multirow[t]{2}{*}{ Model } & \multicolumn{2}{|c|}{$\begin{array}{c}\text { Unstandardized } \\
\text { Coefficients }\end{array}$} & \multicolumn{2}{|c|}{$\begin{array}{l}\text { Standardized } \\
\text { Coefficients }\end{array}$} & \multirow[t]{2}{*}{ Sig. } & \multirow[t]{2}{*}{$\mathrm{F}$} & \multirow[t]{2}{*}{$\mathrm{R}$} & \multirow[t]{2}{*}{$\begin{array}{c}\mathrm{R} \\
\text { Square }\end{array}$} & \multirow[t]{2}{*}{$\begin{array}{l}\text { Adjusted } \\
\text { R Square }\end{array}$} & \multirow{2}{*}{$\begin{array}{l}\text { Std. Error } \\
\text { of the } \\
\text { Estimate }\end{array}$} \\
\hline & B & Std. Error & Beta & $\mathrm{t}$ & & & & & & \\
\hline (Constant) & 2,922 & ,545 & & 5,364 &, 000 & 35,462 & 0,736 & 0,542 & 0,526 & ,82235 \\
\hline VAR6 & ,327 & ,084 & ,356 & 3,893 & ,000 & & & & & \\
\hline VAR2 &,- 366 & ,075 &,- 363 & $-4,897$ & ,000 & & & & & \\
\hline VAR8 &,- 262 & 092 &,- 257 & $-2,858$ & 005 & & & & & \\
\hline
\end{tabular}

Dependent Variable: VAR1 
Table 3. Organizational structures and expansion of the formal power in the companies

\begin{tabular}{ccccccccccc}
\hline Model & \multicolumn{2}{c}{$\begin{array}{c}\text { Unstandardized } \\
\text { Coefficients }\end{array}$} & \multicolumn{2}{c}{$\begin{array}{c}\text { Standardized } \\
\text { Coefficients }\end{array}$} & Sig. & F & R & $\begin{array}{c}\text { R } \\
\text { Square }\end{array}$ & $\begin{array}{c}\text { Adjusted } \\
\text { R Square }\end{array}$ & $\begin{array}{c}\text { Std. Error } \\
\text { of the } \\
\text { Estimate }\end{array}$ \\
\cline { 2 - 8 } & $\mathrm{B}$ & Std. Error & Beta & $\mathrm{t}$ & & & & & & \\
\hline (Constant) & 3,209 &, 473 & & 6,784 &, 000 & 14,761 & 0,574 & 0,330 & 0,307 & 1,00909 \\
VAR6 &,- 368 &, 081 &,- 395 & $-4,539$ &, 000 & & & & & \\
VAR5 &, 231 &, 473 &, 290 & 3,228 &, 002 & & & & & \\
VAR4 &,- 164 &, 078 &,- 190 & $-2,097$ &, 039 & & & & & \\
\hline
\end{tabular}

Dependent Variable: VAR3

systems. In such companies, as a rule, information transfer form simple and oral. For functional structures more difficult systems of transfer and information processing are characteristic. The correlation analysis shows that the organizations with similar structures use all tool kit of information processing. The decentralized organizational structures also show stable relations with information processing, but the variables connected with wide distribution of property and differentiation of business were connected to these communications (to Appendix C).

Hypothesis 4-1. In the organizations with simple organizational structures and the small sizes processing, as a rule, oral and informal (Table 4).
Hypothesis 4-2. In more formal and functional structures processing of information is more difficult, directed on communications and efficiency (Table 5).

Hypothesis 4-3. And at last, in the decentralized organizational structures (matrix and divisional) information streams are directed on adaptation to fast-changing conditions of the market, and in divisions simple and oral forms of interactions prevail. It confirms the thesis about different types and forms of organizational structures and communications even in one diversified company (Table 6).

Hypothesis 4-4. In the companies with simple and functional organizational

Table 4. Structure of the independent variables influencing simple organizational structure

\begin{tabular}{|c|c|c|c|c|c|c|c|c|c|c|}
\hline \multirow[t]{2}{*}{ Model } & \multicolumn{2}{|c|}{$\begin{array}{l}\text { Unstandardized } \\
\text { Coefficients }\end{array}$} & \multicolumn{2}{|c|}{$\begin{array}{l}\text { Standardized } \\
\text { Coefficients }\end{array}$} & \multirow[t]{2}{*}{ Sig. } & \multirow[t]{2}{*}{$\mathrm{F}$} & \multirow[t]{2}{*}{$\mathrm{R}$} & \multirow[t]{2}{*}{$\begin{array}{c}\mathrm{R} \\
\text { Square }\end{array}$} & \multirow[t]{2}{*}{$\begin{array}{l}\text { Adjusted } \\
\text { R Square }\end{array}$} & \multirow{2}{*}{$\begin{array}{l}\text { Std. Error } \\
\text { of the } \\
\text { Estimate }\end{array}$} \\
\hline & B & Std. Error & Beta & $\mathrm{t}$ & & & & & & \\
\hline (Constant) & 2,911 & 0,469 & & 6,206 & 0 & 32,816 & 0,772 & 0,596 & 0,578 & 0,84535 \\
\hline VAR11 & 0,327 & 0,075 & 0,35 & 4,337 & 0 & & & & & \\
\hline VAR1 & 0,279 & 0,093 & 0,257 & 3,016 & 0,003 & & & & & \\
\hline VAR8 & $-0,27$ & 0,095 & $-0,243$ & $-2,85$ & 0,005 & & & & & \\
\hline VAR3 & $-0,177$ & 0,078 & $-0,165$ & $-2,261$ & 0,026 & & & & & \\
\hline
\end{tabular}

Table 5. Structure of the independent variables influencing functional organizational structure

\begin{tabular}{|c|c|c|c|c|c|c|c|c|c|c|}
\hline \multirow[t]{2}{*}{ Model } & \multicolumn{2}{|c|}{$\begin{array}{l}\text { Unstandardized } \\
\text { Coefficients }\end{array}$} & \multicolumn{2}{|c|}{$\begin{array}{l}\text { Standardized } \\
\text { Coefficients }\end{array}$} & \multirow[t]{2}{*}{ Sig. } & \multirow[t]{2}{*}{$\mathrm{F}$} & \multirow[t]{2}{*}{$\mathrm{R}$} & \multirow[t]{2}{*}{$\begin{array}{c}\mathrm{R} \\
\text { Square }\end{array}$} & \multirow[t]{2}{*}{$\begin{array}{c}\text { Adjusted R } \\
\text { Square }\end{array}$} & \multirow{2}{*}{$\begin{array}{l}\text { Std. Error } \\
\text { of the } \\
\text { Estimate }\end{array}$} \\
\hline & B & Std. Error & Beta & $\mathrm{t}$ & & & & & & \\
\hline (Constant) & 1,494 & 0,384 & & 3,887 & 0 & 12,132 & 0,459 & 0,211 & 0,193 & 1,09739 \\
\hline & 0,319 & 0,105 & 0,307 & 3,0 & 0,003 & & & & & \\
\hline VAR12 & 0,262 & 0,111 & 0,24 & 2,366 & 0,02 & & & & & \\
\hline
\end{tabular}

Dependent Variable: VAR7 
structures decision-making process is concentrated at the top level of business hierarchy. Thus information streams simple and oral (Table 7).

\section{Communication of organizational} structure, specialization and differentiation

In the research L. Donaldson I analysed the companies of the USA which were diversified or weren't diversified in 19491959 y. Also I analyzed as structure of each of them I changed towards bigger centralization in the next ten years (19591969). From the diversified companies the structure was changed only by $25 \%(n=48)$ (Donaldson, 1987). However in later empirical researches the importance of organizational structures and their influence on economic efficiency is confirmed. So research Peter G. Klein and Marc R. Saidenberg shows that the banks which differently have been built in holding structures (bank holding companies (BHC's)) have different rates of return
(Klein \& Saidenberg, 2010).

Probably such dissonance arises for the reason that forms and methods of organizational management changed eventually. Today operational control of diversified structures is exercised through new technologies of transfer and information processing.

Hypothesis 5. Specialization with the subsequent differentiation is accompanied by strengthening of level of information processing, transition to the decentralized structures of management. Similar division demands power distribution in the companies more widely.

In our research differentiation is closely connected with processing of information streams for the purpose of improvement of coordination and communication between departments. Thus differentiation is observed in the companies from decentralization of the formal power and organizational structures (Table 8).

Table 6. Structure of the independent variables influencing decentralized organizational structures (divisional and matrix)

\begin{tabular}{|c|c|c|c|c|c|c|c|c|c|c|}
\hline \multirow[t]{2}{*}{ Model } & \multicolumn{2}{|c|}{$\begin{array}{l}\text { Unstandardized } \\
\text { Coefficients }\end{array}$} & \multicolumn{2}{|c|}{$\begin{array}{c}\text { Standardized } \\
\text { Coefficients }\end{array}$} & \multirow[t]{2}{*}{ Sig. } & \multirow[t]{2}{*}{$\mathrm{F}$} & \multirow[t]{2}{*}{$\mathrm{R}$} & \multirow[t]{2}{*}{$\begin{array}{c}\mathrm{R} \\
\text { Square }\end{array}$} & \multirow[t]{2}{*}{$\begin{array}{l}\text { Adjusted } \\
\text { R Square }\end{array}$} & \multirow{2}{*}{$\begin{array}{l}\text { Std. Error } \\
\text { of the } \\
\text { Estimate }\end{array}$} \\
\hline & B & Std. Error & Beta & $t$ & & & & & & \\
\hline (Constant) & 3,224 & 0,578 & & 5,58 & 0 & 23,131 & 0,754 & 0,568 & 0,543 & 0,79174 \\
\hline VAR6 & $-0,256$ & 0,084 & $-0,284$ & $-3,056$ & 0,003 & & & & & \\
\hline VAR9 & $-0,257$ & 0,082 & $-0,248$ & $-3,145$ & 0,002 & & & & & \\
\hline VAR14 & 0,239 & 0,082 & 0,221 & 2,897 & 0,005 & & & & & \\
\hline VAR1 & $-0,228$ & 0,087 & $-0,233$ & $-2,623$ & 0,01 & & & & & \\
\hline VAR10 & 0,173 & 0,083 & 0,148 & 2,08 & 0,04 & & & & & \\
\hline
\end{tabular}

Table 7. Centralization, organizational structures and information processing

\begin{tabular}{|c|c|c|c|c|c|c|c|c|c|c|}
\hline \multirow[t]{2}{*}{ Model } & \multicolumn{2}{|c|}{$\begin{array}{l}\text { Unstandardized } \\
\text { Coefficients }\end{array}$} & \multicolumn{2}{|c|}{$\begin{array}{l}\text { Standardized } \\
\text { Coefficients }\end{array}$} & \multirow[t]{2}{*}{ Sig. } & \multirow[t]{2}{*}{$\mathrm{F}$} & \multirow[t]{2}{*}{$\mathrm{R}$} & \multirow[t]{2}{*}{$\begin{array}{c}\mathrm{R} \\
\text { Square }\end{array}$} & \multirow[t]{2}{*}{$\begin{array}{l}\text { Adjusted } \\
\text { R Square }\end{array}$} & \multirow{2}{*}{$\begin{array}{l}\text { Std. Error } \\
\text { of the } \\
\text { Estimate }\end{array}$} \\
\hline & B & Std. Error & Beta & $\mathrm{t}$ & & & & & & \\
\hline (Constant) & 2,632 & 0,595 & & 4,423 & 0 & 16,269 & 0,593 & 0,352 & 0,330 & 0,92367 \\
\hline VAR8 & $-0,348$ & 0,095 & $-0,362$ & $-3,653$ & 0 & & & & & \\
\hline VAR11 & 0,212 & 0,079 & 0,262 & 2,676 & 0,009 & & & & & \\
\hline VAR15 & 0,225 & 0,099 & 0,197 & 2,279 & 0,025 & & & & & \\
\hline
\end{tabular}

Dependent Variable: VAR9 
Thus, a problem of bureaucratization and coordination, which was noted by J. Chaild (Chaild, 1972), decides through use of progressive forms of information processing in the organizations. The hypothesis confirmed the classical research A. Chandler that the increase in extent of diversification of the company leads to change of organizational structure with functional on divisional (Chandler, 1962).

Influence of methods of adoption of administrative decisions

From the middle of the sixtieth years of last century the theory of "dominant coalition" formulated by Cyert and March, Thompson, Dublin, Chandler and Chaild intensively develops. The concept of the dominating coalition considers organizational structures from the point of view of distribution of the power and process of adoption of strategic decisions in the organization (Chaild, 1972). In the theory of strategic leadership technologies of adoption of key decisions also are considered. It is considered that a role of the director general of chief executive officers (CEO) and consequently concentration of the formal power and authority on his hands is higher, than the power concentrated in hands of Top Management Teams.

Hypothesis 5. Decision-making
centralization at the top level of organizational hierarchy leads to preservation of the enterprise and orientation of the company to domestic policy. The power among shareholders is more widely distributed, the risk of short circuit of the company, and concentration only on the solution of internal problems is lower (Table 9).

Transactional Costs, Management of practices and Corruption

Formulating hypotheses we relied on two points of view. The first - J. Chaild according to which task environment and the organization size in total make impact on processes of adoption of administrative

Table 8. Structure of the independent variables, influencing specialization and differentiation

\begin{tabular}{|c|c|c|c|c|c|c|c|c|c|c|}
\hline \multirow[t]{2}{*}{ Model } & \multicolumn{2}{|c|}{$\begin{array}{l}\text { Unstandardized } \\
\text { Coefficients }\end{array}$} & \multicolumn{2}{|c|}{$\begin{array}{l}\text { Standardized } \\
\text { Coefficients }\end{array}$} & \multirow[t]{2}{*}{ Sig. } & \multirow[t]{2}{*}{ F } & \multirow[t]{2}{*}{$\mathrm{R}$} & \multirow[t]{2}{*}{$\begin{array}{c}\mathrm{R} \\
\text { Square }\end{array}$} & \multirow[t]{2}{*}{$\begin{array}{l}\text { Adjusted } \\
\text { R Square }\end{array}$} & \multirow{2}{*}{$\begin{array}{l}\text { Std. Error } \\
\text { of the } \\
\text { Estimate }\end{array}$} \\
\hline & B & Std. Error & Beta & $\mathrm{t}$ & & & & & & \\
\hline (Constant) & 2,594 & 0,352 & & 7,371 & 0 & 5,173 & 0,384 & 0,147 & 0,119 & 0,93848 \\
\hline VAR12 & 0,169 & 0,09 & 0,189 & 1,875 & 0,064 & & & & & \\
\hline VAR5 & 0,131 & 0,064 & 0,2 & 2,041 & 0,044 & & & & & \\
\hline VAR8 & 0,172 & 0,085 & 0,202 & 2,014 & 0,047 & & & & & \\
\hline
\end{tabular}

Dependent Variable: VAR10

Table 9. Concentration of the power and conservative administrative practices

\begin{tabular}{|c|c|c|c|c|c|c|c|c|c|c|}
\hline \multirow[t]{2}{*}{ Model } & \multicolumn{2}{|c|}{$\begin{array}{c}\text { Unstandardized } \\
\text { Coefficients }\end{array}$} & \multicolumn{2}{|c|}{$\begin{array}{l}\text { Standardized } \\
\text { Coefficients }\end{array}$} & \multirow[t]{2}{*}{ Sig. } & \multirow[t]{2}{*}{$\mathrm{F}$} & \multirow[t]{2}{*}{$\mathrm{R}$} & \multirow[t]{2}{*}{$\begin{array}{c}\mathrm{R} \\
\text { Square }\end{array}$} & \multirow[t]{2}{*}{$\begin{array}{l}\text { Adjusted } \\
\text { R Square }\end{array}$} & \multirow{2}{*}{$\begin{array}{l}\text { Std. Error } \\
\text { of the } \\
\text { Estimate }\end{array}$} \\
\hline & $\mathrm{B}$ & Std. Error & Beta & $\mathrm{t}$ & & & & & & \\
\hline (Constant) & 2,958 & 0,441 & & 6,701 & 0 & 5,414 & 0,391 & 0,153 & 0,125 & 0,92279 \\
\hline VAR9 & 0,209 & 0,087 & 0,239 & 2,391 & 0,019 & & & & & \\
\hline VAR18 & 0,215 & 0,087 & 0,243 & 2,479 & 0,015 & & & & & \\
\hline VAR3 & $-0,162$ & 0,081 & $-0,199$ & $-2,002$ & 0,048 & & & & & \\
\hline
\end{tabular}

Dependent Variable: VAR15 
decisions (Chaild, 1972). The second are the institutional concepts indicating the importance of the institutional environment for economic activity (Williamson, 1985; Williamson, 2000; Oleinik, 2005; Oleinik, 2010). The Russian sociologist of Anton Oleinik claims that "characteristics of the institutional environment should be considered independent variable, and dependent - parameters of administrative structures, including market" (Oleinik, 2005).

Influence of transactional costs us was included for the characteristic of variability of environment. By many authors it was proved, the variability is higher, the conditions of uncertainty are higher and the more organizational structure has to be adaptive and have the developed horizontal communications (Stinchcomb, Burnce and Stulker, Hage and Aiken, Lawrence and Lorsch). At institutsionalist taxes and corruption are a part of transactional costs ("institutional structures of production") and directly influence efficiency of activity of the organization (Coase, 1937; Williamson, 1985; Williamson, 2000).

Corruption a component it was entered by us as a factor reducing economic efficiency of the companies. However corruption problems in Russia have system character and are shown in three forms: in government administration, in business and in society. The former rector of the Russian Economic School, and today professor of economy of the Parisian Institute of Political researches (Sciences Po) Sergey Guriev claims that corruption ruined the Russian economy because institutes of protection of the property rights and a guarantee of observance of contracts were destroyed (Guriev, 2014). In the work "Corruption economy" Mark Levin showed that the scale of corruption depends on the following parameters of bureaucratic system: wage level in public sector, monitoring systems of work of the officials which quality is defined by probability of punishment of the bribe taker, and severity of the laws determining the amount of punishments for bribery (Levin, 2008). A. Ledeneva carried out the analysis of cultural bases of corruption in Russia and revealed existence of informal rules and system of a personal contact, often more important for adoption of political and economic decisions, than formal laws or hierarchies of management (Ledeneva, 1998; Ledeneva, 2006; Ledeneva, 2013).

The main conclusion consists of the latest work that it is necessary to modernize informal networks by means of introspection and gradual reduction of their use. Only it can do "to change system from within" (Ledeneva, 2013).

Hypothesis 6. The progressive forms of government reduce risk of influence of corruption. All types of team management are thus used, specialization and differentiation is entered. Information processing also occurs more intensively for the purpose of coordination of adoption of administrative decisions and fast reaction to market changes.

Our research shows that change of process approaches to management, involvement in decision-making of target groups and design teams can lower a corruption component in business (Table 10).

Hypothesis 7. Than the power among owners or shareholders is more widely distributed, subjects one company smaller the corruption component influences. 
Table 10. Management of practices, information and corruption

\begin{tabular}{|c|c|c|c|c|c|c|c|c|c|c|}
\hline \multirow[t]{2}{*}{ Model } & \multicolumn{2}{|c|}{$\begin{array}{c}\text { Unstandardized } \\
\text { Coefficients }\end{array}$} & \multicolumn{2}{|c|}{$\begin{array}{l}\text { Standardized } \\
\text { Coefficients }\end{array}$} & \multirow[t]{2}{*}{ Sig. } & \multirow[t]{2}{*}{$\mathrm{F}$} & \multirow[t]{2}{*}{$\mathrm{R}$} & \multirow[t]{2}{*}{$\begin{array}{c}\mathrm{R} \\
\text { Square }\end{array}$} & \multirow[t]{2}{*}{$\begin{array}{l}\text { Adjusted } \\
\text { R Square }\end{array}$} & \multirow{2}{*}{$\begin{array}{l}\text { Std. Error } \\
\text { of the } \\
\text { Estimate }\end{array}$} \\
\hline & B & Std. Error & Beta & $\mathrm{t}$ & & & & & & \\
\hline (Constant) & 0 & 0,449 & & 0,001 & 0,999 & 19,622 & 0,685 & 0,469 & 0,445 & 0,8822 \\
\hline VAR17 & 0,498 & 0,076 & 0,529 & 6,579 & 0 & & & & & \\
\hline VAR10 & 0,285 & 0,093 & 0,241 & 3,068 & 0,003 & & & & & \\
\hline VAR14 & 0,269 & 0,089 & 0,246 & 3,006 & 0,003 & & & & & \\
\hline VAR20 & $-0,201$ & 0,078 & $-0,206$ & $-2,579$ & 0,012 & & & & & \\
\hline
\end{tabular}

Dependent Variable: VAR16

The companies having board of directors, as a rule, have adaptation organizational structures (divisional or matrix) and information processing in these companies is directed on increase of efficiency of the companies. In those companies in which the power is distributed among several shareholders/owners gradual differentiation is observed, and decision-making is carried out by progressive group of managers (Appendix C) (Table 11).

Hypothesis 8. The level of taxes is higher, the corruption is higher.

In our research parameters of level of taxes and corruption were included as the most significant factors of environment. And the hypothesis of linear positive communication of taxes and corruption successfully was confirmed (Table 12). Nevertheless, in research it isn't revealed direct dependences of factors of environment with organization structure, the company size, styles of adoption of administrative decisions or information processing. It is rather a fact of dependence of taxes and corruption has macroeconomic character. Increase of taxes on the income of natural persons and value added tax which want to enter since 2018 in Russia, can lead to growth of a corruption component and more intensive formation of already new schemes of evasion from payment.

Table 11. Power distribution among shareholders, collective decision-making, differentiation and corruption

\begin{tabular}{|c|c|c|c|c|c|c|c|c|c|c|}
\hline \multirow[t]{2}{*}{ Model } & \multicolumn{2}{|c|}{$\begin{array}{l}\text { Unstandardized } \\
\text { Coefficients }\end{array}$} & \multicolumn{2}{|c|}{$\begin{array}{l}\text { Standardized } \\
\text { Coefficients }\end{array}$} & \multirow[t]{2}{*}{ Sig. } & \multirow[t]{2}{*}{$\mathrm{F}$} & \multirow[t]{2}{*}{$\mathrm{R}$} & \multirow[t]{2}{*}{$\begin{array}{c}\mathrm{R} \\
\text { Square }\end{array}$} & \multirow[t]{2}{*}{$\begin{array}{l}\text { Adjusted } \\
\text { R Square }\end{array}$} & \multirow{2}{*}{$\begin{array}{l}\text { Std. Error } \\
\text { of the } \\
\text { Estimate }\end{array}$} \\
\hline & B & Std. Error & Beta & $\mathrm{t}$ & & & & & & \\
\hline (Constant) & 0,949 & 0,65 & & 1,461 & 0,148 & 7,905 & 0,512 & 0,262 & 0,229 & 1,33741 \\
\hline VAR3 & 0,394 & 0,115 & 0,313 & 3,415 & 0,001 & & & & & \\
\hline VAR16 & 0,227 & 0,122 & 0,176 & 1,853 & 0,067 & & & & & \\
\hline VAR20 & $-0,311$ & 0,116 & $-0,248$ & $-2,677$ & 0,009 & & & & & \\
\hline VAR10 & 0,311 & 0,146 & 0,204 & 2,134 & 0,036 & & & & & \\
\hline
\end{tabular}

Table 12. Taxes and Corruption

\begin{tabular}{|c|c|c|c|c|c|c|c|c|c|c|}
\hline \multirow[t]{2}{*}{ Model } & \multicolumn{2}{|c|}{$\begin{array}{l}\text { Unstandardized } \\
\text { Coefficients }\end{array}$} & \multicolumn{2}{|c|}{$\begin{array}{l}\text { Standardized } \\
\text { Coefficients }\end{array}$} & \multirow[t]{2}{*}{ Sig. } & \multirow[t]{2}{*}{$\mathrm{F}$} & \multirow[t]{2}{*}{$\mathrm{R}$} & \multirow[t]{2}{*}{$\begin{array}{c}\mathrm{R} \\
\text { Square }\end{array}$} & \multirow[t]{2}{*}{$\begin{array}{l}\text { Adjusted } \\
\text { R Square }\end{array}$} & \multirow{2}{*}{$\begin{array}{l}\text { Std. Error } \\
\text { of the } \\
\text { Estimate }\end{array}$} \\
\hline & B & Std. Error & Beta & $\mathrm{t}$ & & & & & & \\
\hline (Constant) & 1,517 & ,324 & & 4,676 &, 000 & 9,527 & ,306 & ,094 & ,084 & 1,16262 \\
\hline VAR19 &, 323 &, 105 & ,306 & 3,087 &, 003 & & & & & \\
\hline
\end{tabular}


254

\section{CONCLUSION}

As a result of the analysis of theoretical and methodological approaches to research of organizational routines author's interpretation of concept of organizational routine was given and its distinctive features are offered:

1 . The routine is a set of repeating actions of the individual or group of individuals at implementation of the professional activity within one organization;

2. Routines are inherited signs which can be transferred from one organization to another through knowledge of individuals (obvious and implicit), information (personalized and not personalized) and processes (administrative, technological, production, etc.);

3. The basic carrier of routine is the individual.

As a result of the carried-out factorial analysis parameters of organizational routine as sets of information and administrative routines, routines of the power of the founder, genetic, institutional and development routines were specified.

The carried-out correlation and regression analyses showed conditionality of the size of the company and type of organizational structures. It is revealed that the type of organizational structure and power distribution among shareholders/founders has linear dependence. The power among shareholders is more widely distributed, the it is more difficult organizational structures of management.

It is shown that organizational structures are closely connected with intensity of processing of information streams and the organization sizes. The size of the organization and degree of intensity of information processing has impact on a

\section{(2014) $241-262$}

choice of organizational structure. In the organizations with simple organizational structures and the small sizes processing, as a rule, oral and informal. In more formal and functional structures processing of information is more difficult, directed on communications and efficiency. In the decentralized organizational structures (matrix and divisional) information streams are directed on adaptation to fast-changing conditions of the market, and in divisions simple and oral forms of interactions prevail. In the companies with simple and functional organizational structures decision-making process is concentrated at the top level of business hierarchy. Thus information streams simple and oral. In the course of research we came to a conclusion that decision-making centralization at the top level of organizational hierarchy leads to preservation of the enterprise and orientation of the company to domestic policy. The power among shareholders is more widely distributed, the risk of short circuit of the company, and concentration only on the solution of internal problems is lower.

It is revealed as change of approaches to management of the organization can affect a corruption component. The progressive forms of government reduce risk of influence of corruption. Than the power among owners or shareholders is more widely distributed, subjects one company smaller the corruption component influences. At macroeconomic regulation of the taxation in Russia it is necessary to consider that the level of taxes in the country is higher, the corruption is higher.

In the future researches we will try to reveal more close relation between organizational routines and life cycle of the companies. We will add quantitative researches by the qualitative analysis (the 
focused interviews to key actors - heads of the innovative companies). The description of institutes and intra corporate the practices, organizational routines influencing formation and path dependent and institutional analyses in the research corporate management practices incorporation can become the following step.

\section{Acknowledgement}

The author expresses gratitude and appreciation to the editor-in-chief of the Serbian Journal of Management to professor Zivan Zivkovich and dear anonymous reviewers for remarks and offers. Also the author wants to express words gratitude to dear colleagues for the offers stated during the International conference on strategic management of MKSM-2014, organized by Technical faculty in Bor of the Belgrade University.

\section{References}

Abell, P., Felin, T., \& Foss, N.J. (2008). Building micro-foundations for the routines, capabilities, and performance links. Managerial and Decision Economics, 29, 489-502.

Adizes, I. (2008). Managing Corporate Lifecycles.Adizes Institute.

Becker, M.C. (2005). A Framework for Applying Organizational Routines in Empirical Research: Linking Antecedents, Characteristics and Performance Outcomes of Recurrent Interaction Patterns. Industrial and Corporate Change, 14 (5), 817-846.

Chaild, J. (1972). Organizational structure, environment and performance: the role of strategic choice. Sociology, 6, 1-22.

Chandler, A.D. (1962). Strategy and Structure: Chapters in the History of American Industrial Enterprise. Cambridge, Mass.: MIT Press.

Coase, R.H. (1937). The Nature of the Firm. Economica, 4, 386-405.

\title{
ОРГАНИЗАЦИОНЕ РУТИНЕ У РУСКИМ КОМПАНИЈАМА: ПРАКТИЧНИ ПРИМЕРИ
}

\section{Олга Валијева}

\begin{abstract}
Извод
Резултати првог стадијума истраживања, спроведеног током периода 2012-2013 су представљени у овом раду. Истраживања су повезана са проучавањем трансформационог процеса интракорпоративне администрације у пракси руских компанија и корелација са њиховом даљом институционализацијом. Прелиминарни резултати су показали да зависно од времена од оснивања предузећа, праксе везане за прихватање и прилагођавање компаније окружењу могу бити промењиве.Факторска анализа је показала шест типова рутина које утичу на активности компанија. Анализа је показала важност адаптивног типа организационе структуре у управљању и функционисању компанија, прогресивном методу обраде и протока информација, као и у принципима групног доношења одлука. Такође је анализиран и утицај оснивача компаније на управљање.
\end{abstract}

Кључне речи: организационе рутине, институционални елементи, интракорпоративне интеракције, животни циклус организације 
Cohen, M.D., \& Bacdayan, P. (1994). Organizational Routines Are Stored as Procedural Memory: Evidence from a Laboratory Study. Organization Science, 5 (4), 554-568.

Donaldson, L. (1987). Strategy and structural adjustment to regain fit and performance: in defense of contingency theory. Journal of Management Studies, 24 (1), 1-24.

Duncan, R. (1979). What is the organization structure. Organizational Dynamics, 7 (3), 59-81.

Egelhoff, W.G. (1991). Informationprocessing theory and the multinational enterprise. Journal of International Business Studies, 22 (3), 341-368.

Feldman, M.S., \& Pentland, B.T. (2003). Reconceptualizing organizational routines as a source of flexibility and change. Administrative Science Quarterly, 48, 94-118.

Felin, T., \& Hesterly, W.S. (2007). The knowledge-based view, nested heterogeneity, and new value creation: philosophical considerations on the locus of knowledge. Academy of Management Review, 32, 195-218.

Felin, T., Foss, N.J., Heimeriks, K.H., \& Madsen T.L. (2012). Microfoundations of Routines and Capabilities: Individuals, Processes, and Structure. Journal of Management Studies, 49 (8), 1351-1374.

Friesl, M., \& Larty, J. (2013). Replication of Routines in Organizations: Existing Literature and New Perspectives. International Journal of Management Reviews, 15, 106-122.

Gioia, D.A., \& Poole, P.P. (1984). Scripts in Organizational Behavior. Academy of Management Review, 9 (3), 449-459.

Greif, A. (2006). Institutions and the Path to the Modern Economy: Lessons from
Medieval Trade. Cambridge University Press.

Guriev, S. (2014). Corruption ruined the Russian economy. Vedomosti.03.04.2014: http://www.vedomosti.ru/opinion/news/2488 7961/sergej-guriev-korrupciya-razorilarossijskuyu-ekonomiku.

Hannan, M.T., \& Freeman, J. (1977). The population ecology of organizations. American Journal of Sociology, 82, 929-964.

Helfat, C., Finkelstein, S., Mitchell, W., Peteraf, M.A., Singh, H., Teece, D.J., \& Winter, S.G. (2007). Dynamic Capabilities. Understanding Strategic Change in Organizations. Blackwell: Cambridge, MA.

Huber, G. (1982). Organizational information systems: determinants of their performance and behavior. Management Science, 28 (2), 138-155.

Klein, P.G., \& Saidenberg, M.R. (2010). Organizational structure and diversification discount: evidence from commercial banking. The Journal of Industrial Economics, 58 (1), 127-155.

Ledeneva, A.V. (1998). Russia's Economy of Favours. Cambridge University Press.

Ledeneva, A.V. (2006). How Russia Really Works: The Informal Practices That Shaped Post-Soviet Politics and Business. Cornell University Press.

Ledeneva, A.V. (2013). Can Russia Modernise? Sistema, Power Networks and Informal Governance.Cambridge University Press.

Lester, D.L., Parnell, J.A., \& Carraher, S. (2003). Organizational Life Cycle: a fivestage empirical scale. The International Journal of Organizational Analysis, 11 (4), 339-354.

Levin, M.I. (2008). Economics of Corruption. FinancyiBiznes, 2, 52-71. 
Limayem, M., Hirt, S.G., \& Cheung, C.M.K. (2007). How Habit Limits the Predictive Power of Intention: The Case of Information Systems Continuance. MIS Quarterly, 31 (4), 705-737.

Meyer, J.W., \& Rowan, B. (1977). Institutionalized Organizations: Formal Structure as Myth and Ceremony. American Journal of Sociology, 83 (2), 340-363.

Meyer, J.W. (2008). Reflections on Institutional Theories of Organizations, The SAGE Handbook of Organizational Institutionalism - SAGE Publications Ltd.

Mintzberg, H. (1979). The structuring of organizations. Englewood Cliffs, NJ: Prentice-Hall.

Nelson, R.R., \& Winter, S.G. (1982). An evolutionary theory of economic change. Cambridge, MA: Harvard University Press.

Ortiz de Guinea, A., \& Markus, M.L. (2009). Why Break the Habit of a Lifetime? Rethinking the Roles of Intention, Habit, and Emotion in Continuing Information Technology Use. MIS Quarterly, 33 (3), 433444.

Oleinik, A. (2005). Constitution of the Russian Market. Institutional Economy: the textbook. Under a general edition of A. Oleynik. M, INFRA-M.

Oleinik, A. (2010). Market as a Weapon: the Socio-Economic Machinery of Dominance in Russia. New Brunswick, NJ: Transaction Books.

Pentland, B.T., Feldman, M.S., Becker, M.C., \& Liu P. (2012). Dynamics of Organizational Routines: A Generative Model. Journal of Management Studies, 49 (8), 1484-1508.

Teece, D.J. (2012). Dynamic capabilities: routines versus entrepreneurial action. Journal of Management Studies, 49 (8), 1395-1401.

Teece, D.J., Pisano, G., \& Shuen, A.
(1997). Dynamic capabilities and strategic management. Strategic Management Journal, 18, 509-33.

Tolbert, P.S., \& Zucker, L.G. (1983). Institutional sources of change in organizational structure: The diffusion of civil service reform, 1880-1935. Administrative Science Quarterly, 28, 22-39.

Tushman, M.L., \& Nadler, D.A. (1978). Information processing as an integrating concept in organizational design. Academy of Management Review, 3, 613-624.

Valieva, O. (2014). Rutinization of management practice: Evolution and Innovations in the Russian context/ The XV April International Academic Conference on Economic and Social Development (April 14, 2014, Moscow). / Editor-in-chief E.G. Yasin; National Research University "Higher School of Economy" with the assistance of the World bankand the IMF. - M.: ID:http://regconf.hse.ru/uploads/2d0786f63a 99fd99431293f423ddf022e590a332.docx

Verplanken, B., \& Aarts, H. (1999). Habit, Attitude, and Planned Behaviour: Is Habit an Empty Construct or an Interesting Case of Automaticity? European Review of Social Psychology, 10, 101-134.

Winter, S.G. (2003). Understanding dynamic capabilities. Strategic Management Journal, 24, 991-995.

Winter, S.G. (2013). Habit, Deliberation, and Action: Strengthening the Microfoundations of Routines and Capabilities. The Academy of Management Perspectives, 27 (2), 120-137.

Williamson, O.E. (1985). The Economic Institutions of Capitalism - N.Y.: Free Press.

Williamson, O.E. (2000). The New Institutional Economics: Taking Stock, Looking Ahead. Journal of Economic Literature, 38 (3), 595-613.

Wood, W., \& Neal, D.T. (2007). A New 
Look at Habits and the Habit-Goal Interface.

Psychological Review, 114 (4), 843-863.

Zucker, L.G. (1983). Organizations as Institutions. In Advances in Organizational Theory and Research, ed. S.B. Bacharach. Greenwich, 2, 1-43.

Zucker, L.G. (1987). Institutional Theories of Organization. Annual Review of Sociology, 13, 443-464. 


\section{APPENDIX A}

\section{Questionnaire}

We ask you to estimate degree of the importance of the following statements on a scale from 1 to 5 :

(1) - I absolutely not agree, (2) - I don't agree, (3) - it is neutral, (4) - I agree, and (5) - I completely agree.

1. Our company is small both by the absolute size, and in comparison with our competitors

12345

2. We are larger, than the majority of our competitors, but we could be larger

12345

3 . We - the company with the sprayed property, having board of directors

12345

4. In our company the power generally belongs to the founder

12345

5. In our company the power is distributed among several owners/investors

12345

6. The organizational structure of our company can be characterized as simple

12345

7. Our structure, is founded on departments, by the functional principle and becomes more formal

12345

8 . The structure in our company is divisional or matrix, and control systems very difficult

12345

9. Our structure centralized, is a little monitoring systems

12345

10. In our organization there is some specialization (for example, accountants, sales managers, production) and we are gradually differentiated

12345

11. Transfer of orders, exchange and information processing to the companies generally simple and oral

12345

12. Transfer of orders, exchange and information processing are directed on monitoring of activity of the company and ensuring communications between departments

12345

13. Transfer of orders, exchange and information processing are rather formalized and difficult. They are directed on the organization of effective process of production/rendering service and receiving profit

12345

14. Transfer of orders, exchange and information processing are difficult, are used for the best coordination of various actions necessary for fast reaction to market changes

12345

15. Decision-making process is centralized at the top level of the organization.

12345

16 . The majority of decisions in our company is accepted by group of the managers applying methods of the system analysis, but in too time very courageous in the decisions

12345

17. The majority of decisions in our company is accepted by managers, target groups and design teams which try to fix company growth by means of partnership and team work.

12345

18. The majority of decisions in our company is accepted by a small amount of managers with the conservative approach directed on domestic policy

12345

19. Activity of our company is influenced strongly by changes in the tax legislation

12345

20. Activity of our company is influenced strongly by a corruption component

12345 


\section{APPENDIX B}

\section{Total Variance Explained}

\begin{tabular}{|c|c|c|c|c|c|c|c|c|c|}
\hline \multirow{2}{*}{$\begin{array}{l}\text { Co } \\
\mathrm{m} .\end{array}$} & \multicolumn{3}{|c|}{ InitialEigenvalues } & \multicolumn{3}{|c|}{$\begin{array}{c}\text { Extraction Sums of Squared } \\
\text { Loadings } \\
\end{array}$} & \multicolumn{3}{|c|}{$\begin{array}{c}\text { Rotation Sums of Squared } \\
\text { Loadings } \\
\end{array}$} \\
\hline & Total & $\begin{array}{c}\% \text { of } \\
\text { Variance }\end{array}$ & $\begin{array}{c}\text { Cumulative } \\
\%\end{array}$ & Total & $\begin{array}{c}\text { \% of } \\
\text { Variance }\end{array}$ & $\begin{array}{c}\text { Cumulative } \\
\%\end{array}$ & Total & $\begin{array}{c}\% \text { of } \\
\text { Variance }\end{array}$ & $\begin{array}{c}\text { Cumulative } \\
\%\end{array}$ \\
\hline 1 & 4.886 & 24.428 & 24.428 & 4.886 & 24.428 & 24.428 & 4.164 & 20.818 & 20.818 \\
\hline 2 & 2.196 & 10.979 & 35.407 & 2.196 & 10.979 & 35.407 & 2.106 & 10.530 & 31.348 \\
\hline 3 & 1.878 & 9.391 & 44.797 & 1.878 & 9.391 & 44.797 & 1.644 & 8.220 & 39.568 \\
\hline 4 & 1.364 & 6.818 & 51.615 & 1.364 & 6.818 & 51.615 & 1.542 & 7.712 & 47.280 \\
\hline 5 & 1.139 & 5.695 & 57.311 & 1.139 & 5.695 & 57.311 & 1.538 & 7.692 & 54.972 \\
\hline 6 & 1.041 & 5.203 & 62.513 & 1.041 & 5.203 & 62.513 & 1.508 & 7.541 & 62.513 \\
\hline 7 & .949 & 4.746 & 67.259 & & & & & & \\
\hline 8 & .868 & 4.340 & 71.599 & & & & & & \\
\hline 9 & .783 & 3.916 & 75.515 & & & & & & \\
\hline 10 & .760 & 3.798 & 79.313 & & & & & & \\
\hline 11 & .703 & 3.514 & 82.827 & & & & & & \\
\hline 12 & .653 & 3.265 & 86.092 & & & & & & \\
\hline 13 & .561 & 2.805 & 88.897 & & & & & & \\
\hline 14 & .483 & 2.415 & 91.312 & & & & & & \\
\hline 15 & .376 & 1.881 & 93.192 & & & & & & \\
\hline 16 & .346 & 1.732 & 94.924 & & & & & & \\
\hline 17 & .332 & 1.658 & 96.583 & & & & & & \\
\hline 18 & .244 & 1.222 & 97.805 & & & & & & \\
\hline 19 & .240 & 1.202 & 99.007 & & & & & & \\
\hline 20 & .199 & .993 & 100.000 & & & & & & \\
\hline
\end{tabular}

Extraction Method: Principal Component Analysis

\section{KMO and Bartlett's Test}

\begin{tabular}{llr}
\hline Kaiser-Meyer-Olkin Measure of Sampling Adequacy. & & .730 \\
\hline Bartlett's Test of Sphericity & Approx. Chi-Square & 590.534 \\
& df & 190 \\
& Sig. & .000 \\
\hline
\end{tabular}


APPENDIX C

Pearson Correlation

\begin{tabular}{|c|c|c|c|}
\hline \multirow[t]{2}{*}{ Groups } & \multirow[t]{2}{*}{ Variable } & \multicolumn{2}{|c|}{ Values of correlation and variable } \\
\hline & & Positive correlation & Negative correlation \\
\hline \multirow[t]{9}{*}{ 1. Enterprise size } & (1). Small companies & ,610(**) with $(6)$ &,$- 510(* *)$ with $(2)$ \\
\hline & & ,293(**)with (9) &,$- 346(* *)$ with $(3)$ \\
\hline & & $469(* *)$ with $(11)$ &,$- 274(* *)$ with $(7)$ \\
\hline & & &,$- 543(* *)$ with $(8)$ \\
\hline & & &,$- 391(* *)$ with $(13)$ \\
\hline & & &,$- 237(*)$ with $(14)$ \\
\hline & (2). Medium-sized and large companies & ,235(*)with (12) &,$- 510(* *)$ with $(1)$ \\
\hline & & ,322(**)with (13) &,$- 271(* *)$ with $(6)$ \\
\hline & & &,$- 316(* *)$ with $(11)$ \\
\hline \multirow{11}{*}{$\begin{array}{l}\text { 2. Structure of } \\
\text { property and } \\
\text { formal power }\end{array}$} & (3). The sprayed property having Council of &, $349(* *)$ with $(5)$ &,$- 346(* *)$ with $(1)$ \\
\hline & directors &, $314(* *)$ with $(8)$ &,$- 320(* *)$ with (4) \\
\hline & & ,285(**)with (13) &,$- 425(* *)$ with $(6)$ \\
\hline & & &,$- 215(*)$ with $(9)$ \\
\hline & & &,$- 271(* *)$ with $(11)$ \\
\hline & & &,$- 231(*)$ with $(15)$ \\
\hline & (4). Power of the founder & - &,$- 320(* *)$ with $(3)$ \\
\hline & & &,$- 274(* *)$ with $(5)$ \\
\hline & (5). Powerisdistributed &, $349(* *)$ with(3) &,$- 274(* *)$ with $(4)$ \\
\hline & & ,232(*)with $(10)$ &,$- 212\left(^{*}\right)$ with $(15)$ \\
\hline & & ,278(**)with (16) &,$- 227\left(^{*}\right)$ with $(20)$ \\
\hline \multirow{15}{*}{$\begin{array}{l}\text { 3. Organizational } \\
\text { structure of } \\
\text { management }\end{array}$} & (6). Simple &, $610(* *)$ with $(1)$ &,$- 271(* *)$ with $(2)$ \\
\hline & &, $381(* *)$ with $(9)$ &,$- 425(* *)$ with $(3)$ \\
\hline & & ,634(**)with (11) &,- 249 (*)with (7) \\
\hline & & &,$- 606(* *)$ with $(8)$ \\
\hline & & &,$- 322(* *)$ with $(12)$ \\
\hline & & &,$- 529(* *)$ with $(13)$ \\
\hline & & &,$- 316(* *)$ with $(14)$ \\
\hline & (7). Functional and more formal & ,362(**)with (12) &,$- 274(* *)$ with $(1)$ \\
\hline & & ,402(**)with (13) &,$- 249(*)$ with $(6)$ \\
\hline & & ,215(*)with (14) &,$- 294(* *)$ with $(11)$ \\
\hline & (8). Division/Matrix &, $314(* *)$ with $(3)$ &,$- 543(* *)$ with $(1)$ \\
\hline & &, $257(*)$ with $(10)$ &,$- 606(* *)$ with $(6)$ \\
\hline & & ,235(*)with (12) &,$- 520(* *)$ with $(9)$ \\
\hline & &, $521(* *)$ with $(13)$ &,$- 490(* *)$ with $(11)$ \\
\hline & & ,464(**)with (14) & \\
\hline \multirow{9}{*}{$\begin{array}{l}\text { 4. Control, } \\
\text { specialization } \\
\text { and } \\
\text { differentiation }\end{array}$} & (9). Centralization and less Control & ,293(**)with (1) &,$- 215\left(^{*}\right)$ with $(3)$ \\
\hline & & ,381(**)with (6) &,$- 520(* *)$ with $(8)$ \\
\hline & & ,437(**)with (11) &,$- 332(* *)$ with $(13)$ \\
\hline & &, $250(*)$ with $(15)$ &,$- 333(* *)$ with $(14)$ \\
\hline & & &,$- 274(* *)$ with $(16)$ \\
\hline & (10). Specialization & ,232(*)with (5) & - \\
\hline & & ,257(*)with $(8)$ & \\
\hline & & ,259(*)with (12) & \\
\hline & & ,257(*)with (16) & \\
\hline \multirow{11}{*}{$\begin{array}{l}\text { 5. Processing of } \\
\text { information } \\
\text { streams in the } \\
\text { organization }\end{array}$} & (11). Simple, oral &, $469(* *)$ with $(1)$ &,$- 316(* *)$ with $(2)$ \\
\hline & &, $634(* *)$ with $(6)$ &,$- 271(* *)$ with $(3)$ \\
\hline & & ,437(**)with (9) &,$- 294(* *)$ with $(7)$ \\
\hline & & &,$- 490(* *)$ with $(8)$ \\
\hline & & &,$- 457(* *)$ with $(12)$ \\
\hline & & &,$- 566(* *)$ with $(13)$ \\
\hline & & &,$- 460(* *)$ with $(14)$ \\
\hline & & &,$- 283(* *)$ with $(16)$ \\
\hline & & &,$- 243(*)$ with (17) \\
\hline & & &,$- 242(*)$ with (19) \\
\hline & & &,$- 203(*)$ with $(20)$ \\
\hline
\end{tabular}




\begin{tabular}{|c|c|c|c|}
\hline & (12). Communication & $\begin{array}{l}, 235(*) \text { with }(2) \\
, 362(* *) \text { with }(7) \\
, 235(*) \text { with }(8) \\
, 259(*) \text { with }(10) \\
, 396(* *) \text { with }(13) \\
, 355(* *) \text { with }(14) \\
, 339(* *) \text { with }(16) \\
, 244(*) \text { with (17) }\end{array}$ & $\begin{array}{l}-, 322(* *) \text { with(6) } \\
-, 457(* *) \text { with(11) }\end{array}$ \\
\hline & (13). Formals and Difficult, for production & ,322(**)with (2) &,$- 391(* *)$ with $(1)$ \\
\hline & efficiency & $\begin{array}{l}, 285(* *) \text { with (3) } \\
, 402(* *) \text { with (7) } \\
, 521(* *) \text { with (8) } \\
, 396(* *) \text { with }(12) \\
, 510(* *) \text { with (14) } \\
, 218(*) \text { with (16) }\end{array}$ & $\begin{array}{l}-, 529(* *) \text { with }(6) \\
-, 332(* *) \text { with }(9) \\
-, 566(* *) \text { with }(11)\end{array}$ \\
\hline & (14). Difficult, for adaptation & ,215(*)with (7) &,$- 237\left({ }^{*}\right)$ with (1) \\
\hline & & ,464(**)with $(8)$ &,$- 316(* *)$ with $(6)$ \\
\hline & &, $355(* *)$ with $(12)$ &,$- 333(* *)$ with $(9)$ \\
\hline & &, $510(* *)$ with $(13)$ &,$- 460(* *)$ with $(11)$ \\
\hline & &, $367(* *)$ with (16) & \\
\hline & & ,265(**)with (17) & \\
\hline \multirow{14}{*}{$\begin{array}{l}\text { 6. Decision- } \\
\text { making processes }\end{array}$} & &, $214(*)$ with $(20)$ & \\
\hline & (15). Centralization on the top level &, $250(*)$ with (9) &,$- 231(*)$ with (3) \\
\hline & & ,278(**)with $(5)$ &,$- 212(*)$ with $(5)$ \\
\hline & & ,257(*)with (10) & \\
\hline & &, $339(* *)$ with (12) & \\
\hline & & ,218(*)with (13) & \\
\hline & &, $367(* *)$ with (14) & \\
\hline & &, $579(* *)$ with (17) & \\
\hline & (16). Groups of Top-managers, are based & - &,$- 274(* *)$ with (9) \\
\hline & on the system analysis, courageous & &,$- 283(* *)$ with $(11)$ \\
\hline & (17). Partnership and team work & ,244(*)with (12) &,$- 243\left({ }^{*}\right)$ with $(11)$ \\
\hline & &, $265(* *)$ with (14) & \\
\hline & &, $579(* *)$ with $(16)$ & \\
\hline & (18). Centralization $* * *$ & - & - \\
\hline \multirow{3}{*}{$\begin{array}{l}\text { 7. Influence of } \\
\text { transactional } \\
\text { costs }\end{array}$} & (19). Taxes & ,306(**)with (20) &,$- 242(*)$ with $(11)$ \\
\hline & (20). Corruption & ,214(*)with (14) &,$- 227(*)$ with $(5)$ \\
\hline & & ,306(**)with (19) &,$- 203(*)$ with $(11)$ \\
\hline
\end{tabular}

*** Correlation is absent;

** Correlation is significant at the 0.01 level (2-tailed);

*Correlation is significant at the 0.05 level (2-tailed). 